\title{
Adaptation of energy metabolism to undernutrition in adult ewes
}

\author{
I Ortigues ${ }^{1}, \mathrm{M} \mathrm{Houzel}^{1}$, D Durand ${ }^{2}, \mathrm{M}$ Vermorel ${ }^{2}$ \\ 1 INRA, laboratoire Lactation et Elevage des ruminants, Theix; \\ 2 INRA, laboratoire Croissance et Métabolismes des herbivores, Theix, \\ 63122 Saint-Genès-Champanelle, France
}

The objectives of the present experiment were to determine to what extent tissue beds, such as portal drained viscera (PDV), liver and hindquarters (HQ), could be responsible for the adaptation of energy metabolism to undernutrition, since these compartments altogether represent up to $80 \%$ of total animal energy expenditure (EE) (Ortigues, 1991).

Two adult non producing ewes (A and B, 55.5 $\mathrm{kg}$ ), surgically equipped with chronic catheters were used. Blood flows through the liver and the posterior aorta were measured by paramino hippuric acid (PAH) dilution and an ultrasonic probe, respectively. After recovery from surgery, animals were fed (8 meals/d) Dactylis Glomerata hay, first at maintenance $(84 \mathrm{kcal}$ ME $\cdot \mathrm{kg}$ initial $\left.L W-0.75 \cdot d^{-1}\right)$ for 3 wk $(-3$ to -1$)$ and then at half-maintenance for $7 \mathrm{wk}(+1$ to +7$)$. Total animal $E E$ was measured every 2 wk by indirect calorimetry and tissue $\mathrm{EE}$ (calculated from tissue $\mathrm{O}_{2}$ consumption) was measured every wk.

Whole animal EE averaged 1714 on wk 1 and decreased exponentially with time to 1290 and $1100 \mathrm{kcal} / \mathrm{d}$ on $\mathrm{wk}+2$ and +6 . The overall decrease $(-36 \%)$ was greater than that of liveweight $(-19 \%)$, which resulted in a reduction in the calculated maintenance requirements by an average

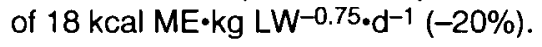

At tissue level, EE could only be measured in the PDV (until wk +2 , ewe A), the total splanchnic tissues (ewe B), and $\mathrm{HQ}$ (ewes A, B) due to some loss in catheter patency. EE of $H Q$ averaged $218 \mathrm{kcal} / \mathrm{d}$ and was not affected by the level of feeding or duration of underfeeding. All measured changes in total animal EE $(-439$ $\mathrm{kcal} / \mathrm{d}$ on wk +2 in ewe $A$, and -409 and 625 on wk +2 and +6 in ewe B) could be attributed to the splanchnic tissues $(-191$ $\mathrm{kcal} / \mathrm{d}$ on wk +2 for the PDV in ewe $A$, and -618 and -705 for the total splanchnic tissues in ewe $B$ on $w k+2$ and +6 respective(y). These changes resulted from cumulative decreases in portal (2.66 vs $1.86 \mathrm{l} / \mathrm{min}$ ewe A) and hepatic (3.18 vs 1.99 vs 1.82 l/ $\min$ in $w k-1,+2$ and +6 , ewe B) blood flows, and in the percentage of oxygen extraction by PDV (20.7 vs $14.8 \%$, ewe A) and splanchnic tissues (42.5 vs 28.6 vs $31.1 \%$, ewe $B$, respectively) with level of feeding and duration of undernutrition.

After 7 wk of underfeeding ewes were slaughtered. In vivo metabolic activity of adipose tissue free-PDV, liver and deboned-HQ was calculated to be $0.95-1.25$, 2.7-2.8 an $0.28 \mu \mathrm{mol} \mathrm{O}_{2}$ consumed $/ \mathrm{min} / \mathrm{g}$ wet tissue.

Consequently, undernutrition resulted in a repartitioning of energy metabolism between the different body tissues whereby energy metabolism of peripheral tissues was maintained at the expense of that of splanchnic tissues.

Ortigues I (1991) Reprod Nutr Dev 31, 593-616 